\title{
RINKOS SENTIMENTŲ PROGNOZAVIMAS NAUDOJANT DIRBTINI INTELEKTĄ
}

\author{
Nijolė MAKNICKIENĖ, Jovita MASĖNAITÉ* \\ Vilniaus Gedimino technikos universitetas, Verslo vadybos fakultetas, \\ Finansu inžinerijos katedra, Saulètekio al. 11, LT-10223, Vilnius, Lietuva \\ "El.paštas jovita.masenaite@stud.vgtu.lt
}

\begin{abstract}
Santrauka. Kiekvienas investuotojas susiduria su efektyvių investicinių sprendimų prièmimo problema. Yra daug metodų, kuriais stengiamasi išanalizuoti finansų rinkoje vykstančiu pokyčių priežastis bei remiantis tokia informacija numatyti ateities tendencijas. Vienas iš būdų yra investuotojų sentimentų prognozavimas. Šio straipsnio tyrimo tikslas yra atlikti skirtingų investuotojų sentimentų prognozavimą ir ịvertinti prognozavimui naudojamo modelio patikimumą, t. y. siekiama atrasti patikimą sentimentų prognozavimo algoritmą. Tyrimui naudojamas dirbtinio intelekto giliojo mokymosi ilgos trumpalaikès atminties (LSTM) tinklų algoritmas bei grafinis gautų rezultatų vaizdavimas. Atlikus tyrimą buvo pastebèta, kad kiekvienu sentimentų prognozavimo atveju gauta paklaida (RMSE) buvo labai maža, o tai reiškia, kad prognozavimui naudojamas algoritmas yra labai patikimas. Sentimentų prognozavimas kartu su racionaliais prognozavimo metodais gali papildyti prekybos strategiją ar paramos sistemą investuotojui.
\end{abstract}

Reikšminiai žodžiai: investuotojo elgsena, rinkos sentimentai, dirbtinis intelektas, giliojo mokymosi metodas, ilgos trumpalaikès atminties tinklai, prognozavimas.

\section{İvadas}

Individualūs investuotojai yra vieni pagrindinių finansų rinkos veiksnių, nuo kurių priklauso finansinių priemonių vertès kitimas. Siekiant būti pasiruošus ịvairiems rinkos pokyčiams bei juos numatyti yra būtina nagrinèti individualių investuotojų elgseną finansų rinkose. Jeigu didžioji dalis investuotojų nusiteikę optimistiškai, jie skatina finansinių priemoniu vertès rinkoje kilimą, jeigu pesimistiškai - kritimą. Todèl yra svarbu stebèti investuotojų priimamus sprendimus ir bandyti išsiaiškinti pagrindines priežastis bei motyvus kodèl konkretūs investiciniai sprendimai yra priimami. Tačiau dauguma investuotojų sprendimus priima remdamiesi savo psichologiniais motyvais, o tokiu būdu priimamus sprendimus yra labai sunku nuspèti. Siekiant kuo tiksliau išsiakinti individualių investuotojų elgesio priežastis yra matuojami rinkos sentimentai. Pagal juos investuotojai skirstomi i skirtingas grupes ir bandoma atrasti bendrą jų elgesį siejančiu panašumų modelị, kad būtų galima numatyti rinkoje vyraujančias tendencijas. Vienas iš būdų investuotojams priimti efektyvesnius investavimo sprendimus yra rinkos sentimentų prognozavimas, nes žinodami kokie sentimentai vyraus artimiausioje ateityje investuotojai gali bandyti nuspèti ar konkrečios finansinės priemonės verte kils ar kris ir tuo remdamiesi priimti jiems palankius investicinius sprendimus. Mokslinèje literatūroje vieni tinkamiausių būdų laiko eilutès prognozėms atlikti išskiriami dirbtinio intelekto algoritmai. Dirbtinis intelektas yra naudojamas siekiant atkartoti žmogaus smegenų funkcionalumą, jis susideda iš neuroninių tinklų, kurių pagalba geba pats apsimokyti iš didelio duomenų kiekio ir priimti sprendimus remiantis stebèta informacija. Tačiau moksliniuose darbuose rinkos sentimentų prognozavimui dirbtinio intelekto algoritmai dar nèra pačiai naudojami. Šio straipsnio esmé yra atrasti patikimiausią investuotojų sentimentu prognozavimo algoritmą.

Tyrimo objektas - investuotojų sentimentai.

Tyrimo problema - kaip atlikti patikimą investuotojų sentimentų prognozavimą.

Tikslas - atlikti skirtingų investuotojų sentimentų prognozavimą ir įvertinti prognozavimui naudojamo modelio patikimumą.

Uždaviniai tikslui pasiekti:

-išanalizuoti investuotojų elgsenos sampratą mokslinèje literatūroje;

- išanalizuoti investuotojų sentimentų matavimo būdus ir dirbtinio intelekto naudojimo galimybes;

- atlikti investuotojų sentimentų prognozavimą bei naudojamo algoritmo patikimumo įvertinimą. 


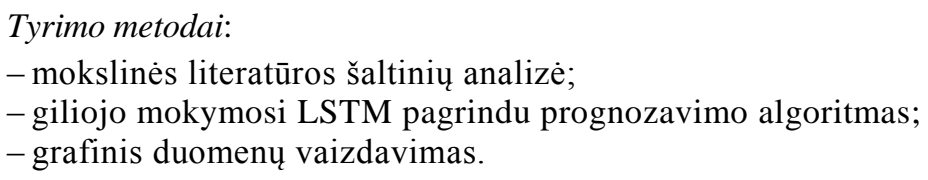

\section{Investuotojų elgsenos samprata ir klasifikacija}

Kiekvieno investuotojo pagrindinè veikla yra pastovus sprendimų prièmimas, nepaisant to, kokios yra investuotojo naudojamos finansinès priemonès. Visi investuotojai norėdami užsiimti investavimo veikla privalo atsakyti i daugybę skirtingų klausimu ir nesvarbu kiek konkretus investuotojas turi patirties, ar jis tik pradedantysis, ar jau pažengęs investavimo srityje. Formuodami savo investicinị portfelį investuotojai turi pasirinkti kokios finansinès priemonés i jų portfeli bus ịtrauktos, kokiu santykiu bus paskirstytos investicijos, kada ir kokia rizika bus prisiimta, kam paskirti valdyti investicini portfeli ir kt. (Barber ir Odean, 2013).

Investuotojai sugeba suformuoti efektyvų investicinị portfelį bei parinkti efektyvias investicines priemones. Tai reiškia, kad investuotojai sprendimus priima remdamiesi skaičiavimais ir savo racionaliu mąstymu. Tačiau šioms kertinèms tradicinių finansų teorijos nuostatoms prieštarauja jau keliasdešimt metų plètojama ir nagrinèjama finansų elgsenos teorija. Tai yra mokslas, kuris nagrinejja situacijas esančias rinkoje, kuriose figūruojantys dalyviai demonstruoja savo riboto racionalumo lemiamus veiksmus (Picasso et al., 2019). Finansų elgsenos teorija susiformavo tada, kuomet buvo išsiaiškinta, kad atliekant ekonominių, investicinių sprendimų prognozavimą negalima remtis tik racionalumu. Žmogaus elgsena nèra visuomet paremta tikimybių teorija, matematika ir skaičiavimais, todèl finansų elgsena nagrinèja, kokia yra emocinių veiksnių ịtaka daroma rinkos pokyčiams, kadangi investuotojai nèra racionalūs. Bandoma išsiaiškinti kodèl investuotojai elgiasi neracionaliai, kokie yra to motyvai, siekiama suskirstyti investuotojus pagal nuokrypius nuo racionalios elgsenos, kad būtų galima stebėti rinkoje vyraujančias tendencijas ir prognozuoti galimus pakitimus. Tačiau vieno modelio, kaip galima būtų klasifikuoti investuotojus pagal jų elgseną, dar nèra suformuota (Lapanan 2018).

Bikas ir Kavaliauskas (2010) nuokrypius nuo racionalios elgsenos siūlo skirstyti ị dvi rūšis: kognityvinius nukrypimus ir pirmumo klaidas. Kognityviniai nukrypimai skirstomi ị atskiras sritis:

- Atstovavimas. Sprendimų prièmėjų nuomone, labiau reprezentatyvus rezultatas yra tas, kuris ịvyksta neatsižvelgiant ị tikimybes;

- Pasitikejjimas. Tendencija, kad investuotojas yra pernelyg užtikrintas atliekant veiksmus, t. y. pervertintas pasitikèjimas savo priimamais sprendimais bei prognozavimo sugebejjimais;

- Stovejimas/inkaras. Tendencija, kad priimami sprendimai jau yra paveikti investuotojų patirties;

- Tinkamumas. Lengvai prieinama informacija turi didesnę vertę priimant sprendimus;

- Klaida. Spèjimas, kad kokia nors tendencija pakeis savo krypti.

Pirmumo klaidos skirstomos ị tokias sritis:

- Rèminimas. Investuotojai „rèmina“ savo priimamus sprendimus pagal nuokrypius, t. y. grąžą ir nuostolius, nuo subjektyvaus atskaitos taško;

- Nuostolio vengimas. Investuotojas yra jautresnis nuostoliui, o ne pelnui;

- Rizikos ieškojimas nuostoliams padengti. Investuojama saugiai norint apsaugoti savo pelną, tačiau yra daug rizikuojama siekiant padengti nuostolius;

- Subjektyvus tikimybès iškraipymas. Investuotojai remiasi labai subjektyviais sprendimų „svoriais“, kurie pervertina mažą didelio pelno tikimybę ir neịvertina didelès mažo pelno ar didelio nuostolio tikimybès.

Kitokị investuotojų skirstymą pagal nukrypimus nuo racionalios elgsenos pateikia Barber ir Odean (2013). Autoriai investuotojų elgsenos nukrypimus skirsto ị dvi rūšis: kognityvinius nukrypimus ir emocinius nukrypimus. Kognityviniai nukrypimai skirstomi į tokias sritis:

- Per didelis pasitikejimas. Investuotojo pervertintas tikejjimas savo priimamais sprendimais bei gabumais;

- Atstovavimas. Naujai igyta patirtis yra priskiriama visiškai kitokiam patyrimui negu iš tikrujų turètų būti;

- Stovèjimas/inkaras ir prisiderinimas. Prie kažkokios ịsivaizduojamos pradinės reikšmès derinami veiksmai;

- Kognityvinis disonansas. Kai naujai gauta informacija prieštarauja investuotojo esamam supratimui;

- Tinkamumas. Remiantis anksčiau igyta investavimo patirtimi yra apskaičiuojama konkreti tikimybė;

- Priskyrimas. Situacija kai investuotojas prisiskiria sau sékmingus ịvykius bei patirtị;

- Kontrolès iliuzija. Investuotojas mano, kad galutinis rezultatas yra jo rankose ir jis kontroliuoja aplinkybes;

- Konservatizmas. Kai investuotojas nekreipia dèmesio i naują informaciją ir tvirtai laikosi savo nuomonès; 
- Neaiškumo vengimas. Situacijose, kuriose pasitaiko dviprasmybių, investuotojai ima dvejoti savo veiksmais;

- Mentalinès sąskaitos. Investuotojo tendencija įvertinti ir koduoti ekonominius rezultatus grupuojant turtą;

- Patvirtinimas. Yra akcentuojamos idejos, kurios patvirtina investuotojo issitikinimus, o nuvertinamos tos, kurios prieštarauja;

- Tariamas numatymas. Kai praejjus konkretiems įvykiams, investuotojas mano žinojęs, kad taip turèjo būti;

- Naujumas. Kai investuotojas remiasi daugiau nauja informacija, nei senesnèmis ir patikrintomis žiniomis;

- Rèminimas. Tendencija, kad priimami sprendimai pagal tai, kokia situacija tuo konkrečiu metu parodoma.

O emociniai nukrypimai skirstomi ị tokias sritis:

- Šelpimas. Investuotojai konkretų turtą vertina labiau, kai jie yra to turto savininkai, t. y. gali juo disponuoti;

- Savikontrolè. Investuotojo elgesio tendencija, kai jis vartoja šiandien rytojaus sąskaita;

- Optimizmas. Pernelyg optimistiškas požiūris trukdo matyti tikrus faktus bei realią situaciją;

- Nuostolio vengimas. Investuotojo jaučiamas didesnis jautrumas nuostolio išvengimui, nei pelno uždirbimui;

- Apgailestavimo vengimas. Kai nesiimama ryžtingu veiksmų, nes manoma, kad jie vis tiek bus netinkami;

- Faktinè padėtis. Kai investuotojas yra iš anksto nuteikiamas pasirinkti tokị sprendimą, kuris patvirtina egzistuojančias sąlygas, o ne alternatyvas, kurios galètų atnešti pokyčius finansinèje rinkoje.

Kiekviena sritis turi konkrečių investuotojo panašių elgesio bruožų visumą, todèl stebint vieną ar kitą investuotoją ir jo atliekamus veiksmus pagal panašius elgesio bruožus galima jị identifikuoti ir priskirti tam tikrai sričiai, kurios pagalba yra galimybė numatyti ir suprasti kokie jo elgesio motyvai bei kokie galètų būti investuotojo tolimesni sprendimai. Tačiau tai yra tik keli būdai kaip būtų galima skirstyti investuotojus pagal jų elgesị ir tai nereiškia, kad tik kažkuriuo iš šių klasifikavimo būdų turètume remtis stebint rinkos tendencijas, nes skirtingose situacijose investuotojai gali elgtis visiškai skirtingai. Šiuolaikinès finansų elgsenos mokslininkai pateikia daug investuotojų tipo nustatymo modelių, kurie padeda identifikuoti investuotojus ir bandyti prognozuoti finansinių rinkų elgseną, o investuotojų elgsenos supratimas gali apsaugoti nuo klaidingų sprendimų prièmimo bei profesionaliau patarti investuotoju (Ryu et al., 2017). Makroekonominiu lygmeniu yra matuojami rinkos sentimentai.

\section{Rinkos sentimentų reikšmė ir matavimas}

Investuotojų sentimentai, tai yra investuotojų elgesio priklausomumas nuo jų psichologijos. Faktiniai investuotojų nukrypimai nuo racionalumu paremto elgesio yra panašaus pobūdžio, o ne atsitiktiniai. Vadinasi tos priimamų sprendimų klaidos, kurias nuolat kartoja dauguma investuotojų, sudaro investuotojo sentimentus (Yang ir Wu, 2019). Nagrinejjant mokslinę literatūrą, pastebėta, kad autoriai skirtingai apibūdina investuotojų sentimentus, pabrèždami vieną ar kitą aspektą. Ben-Rephael et al. (2010) sentimentus apibrèžia iškeldami klausimą, ar investuotojas būdamas tam tikroje situacijoje dẻl bet kokio pašalinio veiksnio jaučiasi pernelyg pesimistiškas ar optimistiškas. Autoriai pabrèžia, kad esami investuotojų sentimentai daro ịtaką jų požiūriui ị ateities ịvykius bei priimamus sprendimus, t. y. investuotojai, pasižymintys neigiamais sentimentais, linkę priimti pesimistiškus pasirinkimus, o investuotojai, pasižymintys teigiamais sentimentais - optimistiškus. Bouteska (2019) investuotojų sentimentus apibūdina kaip investuotojų nuotaiką sprendimo prièmimo metu. Tačiau rinkos sentimentai yra platesnè sąvoka, nes ji aprépia visapusiškai klaidingą suvokimą, kuris gali daryti įtaką neteisingam investicinių priemonių kainų nustatymui. Investuotojų klaidingi ịsitikinimai gali susiformuoti tuomet, kai investuotojai klaidingai naudoja teisingą informaciją arba teisingai naudoja klaidingą informaciją (Zhou, 2017).

Individualių investuotojų sentimentai yra naudojami kaip priešingas rodiklis valiutų kursams ar finansiniams indeksų veiksmams atlikti. Sentimentų prognozès investuotojams suteikia papildomos informacijos ir gali lemti geresnius sprendimus finansų rinkose, todèl sudarant informacinị duomenų rinkinị prognozei nustatyti yra būtina matuoti investuotojų sentimentus (Maknickienè ir Vaškevičiūtè, 2017).

Investuotojų sentimentų matavimus galima suskirstyti ị tris kategorijas, t. y. tiesioginiai, netiesioginiai ir meta priemonès, remiantis tuo, kaip yra kaupiami duomenys matavimui (He et al., 2019). Tiesioginis sentimentų matavimas yra atliekant investuotojų apklausas, kuriose tiesiogiai klausiama kaip žmogus jaučiasi esant dabartinėms ar būsimoms ekonominėms ir akcijų rinkos sąlygoms, o netiesioginis matavimas atspindi ekonominius ir finansinius kintamuosius, galinčius užfiksuoti investuotojų mintis (Beer ir Zouaoui, 2012). Dauguma empirinių tyrimų kaip netiesioginị sentimentų matavimą naudoja rinkos rodiklius. Trečioji kategorija yra tiesioginių ir 
netiesioginių sentimentų matavimų derinys, kuris yra sudètinė viso sentimentų matavimo dalis (Pandey ir Sehgal, 2019).

Šiame darbe yra naudojami AAII (Amerikos individualių investuotojų asociacijos) duomenys (AAII Investor Sentiment Survey, 2019). AAII atlieka individualių investuotojų sentimentų tyrimą, kuris matuoja investuotojų procentinị pasiskirstymą ir rūšiuoja juos ị bulių (pozityvią), meškų (negatyvią) arba neutralią kategorijas. Visi AAII nariai yra apklausiami kiekvieną savaitę ir tik vienas kiekvieno nario balsas yra priimamas (Maknickiene et al., 2018).

\section{Dirbtinio intelekto naudojimas}

Dirbtinis intelektas (angl. Artificial Intelligence, AI) suteikia idealią galimybę fiksuoti investuotojų sentimentus, nes dirbtinis intelektas gali tiesiogiai ịvertinti investuotojų sentimentus be iš anksto nustatytų emocijų duomenų ar pasirinkto specifinio komponento ir tokiu būdu padèti sumažinti prognozavimo šališkumą, kurị sukelia subjektyvus ịsikišimas ar ịprastos aproksimacijos klaidos. Be to, turẻdamas nepriklausomą giliojo mokymosi gebejjimą, dirbtinis intelektas gali tiksliai nurodyti, kokia yra žodžio sentimentalumo reikšmė konkrečioje situacijoje, atsižvelgiant ị tai, kad vienas žodis gali atspindèti skirtingą sentimento laipsnį skirtingų scenarijų atžvilgiu (Ruan et al., 2020). Dirbtinio intelekto pagalba yra siekiama atkartoti žmogaus smegenų funkcionalumą, bandoma atlikti veiksmus, kurios sugeba atlikti pats žmogus, t. y. siekiama sukurti žmogaus smegenų atliekamų intelektinių veiksmų imitaciją (Paschen et al., 2020).

Giliojo mokymosi metodas (angl. Deep Learning, DL) yra vienas pažangiausių mašininio mokymosi metodų, jis sulaukè daug dėmesio tyrimų srityje, kadangi jo pagalba galima ịveikti priklausomybę nuo rankomis sukurtų funkcijų su kuriomis susiduria tradiciniai mokymosi algoritmai. Giluminis mokymasis arba giluminiai neuroniniai tinklai (angl. Deep Neural Networks, DNN) paprastai susideda iš dviejų etapų: mokymo žingsnio, skirto optimizuoti modelio tikslumą, ir išvados fazès, kai modelis naudojamas klasifikavimui ar prognozavimui. Giluminio mokymosi metu sekliausias nervų tinklas gali geriau parodyti sudètingas aukšto matmens funkcijas ir pritaikyti išgautų duomenų savybes kitose vietose, o jis gali rasti tikrajị ryšį iš pirminių duomenų (Chen et al., 2019). Šiais laikais giliojo mokymosi metodas naudojamas ịvairiose srityse, ịskaitant didžiųjų duomenų analizę ir skirtingas programas, tokias kaip modelio atpažinimas, kalbos atpažinimas, kompiuterinis matymas, natūralios kalbos apdorojimas, įsibrovimo aptikimas ir medicininès prognozès (Boulemtafes et al., 2020). Giliojo mokymosi patirtis ypač pagerèja pasitelkiant galingas infrastruktūras, tokias kaip debesys ir mokymosi bendradarbiaujant modelį. Kadangi vartotojo įrenginiai yra riboti išteklių atžvilgiu, išeitis yra resursų reikalaujančių operacijų perkėlimas i i išorinę laikmeną su didelès galios skaičiavimu ir didele talpa, pavyzdžiui, perkèlimas ị debesị (Boulemtafes et al., 2020).

Vienas pažangiausių giliojo mokymosi metodų yra ilgos trumpalaikès atminties (angl. Long Short-Term Memory, LSTM) tinklai, kurie skirti sekos mokymosi užduotims, tokioms kaip rašysenos atpažinimas, kalbos atpažinimas arba laiko eilučių prognozavimas (Fischer ir Krauss, 2018). Ilgos trumpalaikès atminties tinklai, tai yra rekurentiniai neuroniniai tinklai galintys išmokti ilgalaikes priklausomybes. Jie turi „atminties elementus“, kurie gali išlaikyti informaciją neapibrěžtą laiką (Vo et al., 2019).

Atlikus skaičiavimus su MATLAB programa (Matlab..., 2019) naudojant ilgos trumpalaikès atminties metodą gautų prognozių tikslumui ịvertinti yra apskaičiuojamas RMSE (angl. Root Mean Squared Error, RMSE) paklaidos matas pagal formulę (Šiurkutè ir Jakaitienè, 2009):

$$
R M S E=\sqrt{\frac{1}{T} \sum_{t=1}^{T}\left(\hat{y}_{t}-y_{t}\right)^{2}},
$$

kur $T$-stebinių skaičius, $\hat{y}_{t}$ - prognozuojama reikšmè, o $y_{t}$-stebèta reikšmè, kai $t=1, \ldots, T$.

Šio kriterijaus privalumas yra, tas, kad pakèlus kvadratu gautą reikšmę, dideli nuokrypiai yra dar labiau išryškinami. Vadinasi svarbu, kad gauta paklaida būtų kuo mažesnè, siekiant gauti kuo tikslesnị prognozavimo modelị.

\section{Sentimentų prognozavimas naudojant giliojo mokymosi metodą}

Kaip ir prieš tai buvo minèta, tyrimo metu naudojami AAII sentimentų apklausų istoriniai duomenys. Istorinių duomenų laikotarpis yra nuo 1988 metų sausio 8 dienos iki 2019 metų gruodžio 19 dienos. Kadangi reikšmès buvo fiksuojamos kas savaitę, tai iš viso tyrime buvo naudojami 1666 duomenys. Kiekvienas duomuo suskirstytas ị tris kategorijas (bulių, meškų, neutralią) pagal investuotojų sentimentus, išreikštus procentais nuo visų apklausose dalyvavusių individualių investuotojų. Tyrimo metu kiekviena investuotojų kategorija nagrinëjama atskirai.

Investuotojų sentimentai buvo prognozuojami naudojant giliojo mokymosi LSTM metodą su MATLAB programa. $90 \%$ visų duomenų buvo naudojami modelio apmokymui, o paskui vietoje istorinių $10 \%$ paskutinių duomenų buvo atliktos prognozès. Tokiu būdu galima tikrinti ir ịsitikinti kiek tiksliai naudojamas neuroninis tinklas 
geba prognozuoti, kadangi prognozuotas reikšmes galima palyginti su jau egzistuojančiomis istorinèmis reikšmėmis. Tai atlikus galima prognozuoti ateities reikšmes.

Pirmoji nagrinėjama kategorija yra bulių arba, kitaip tariant, tai yra teigiami investuotojų sentimentai. Tai yra investuotojai, kurie yra suinteresuoti konkrečios finansinès priemonès vertès augimu ir dèl ateities yra nusiteikę pozityviai (Kumari, 2019). Visų pirma buvo atliktas LSTM modelio apmokymas, t. y. modelis atliko istoriniu duomenų stebẻjimą daug kartų ir ieškojo sąsajų tarp pasikartojančių panašaus pobūdžio kitimų. Apmokytas modelis atliko visos laiko eilutès prognozavimą ir buvo apskaičiuotos paklaidos (RMSE) tam, kad būtu galima ịvertinti kiek daug naudojamo modelio prognozių reikšmės yra nutolusios nuo realių reikšmių, t. y. paklaida parodo modelio prognozavimo tikslumą.

1 paveiksle yra pateikti modelio mokymosi ir apskaičiuotų paklaidų grafikai. Teigiami sentimentai išreikšti procentais nuo visų balsavusių individualių investuotojų, o prognozavimo tikslumui vertinti skaičiuojamas RMSE.
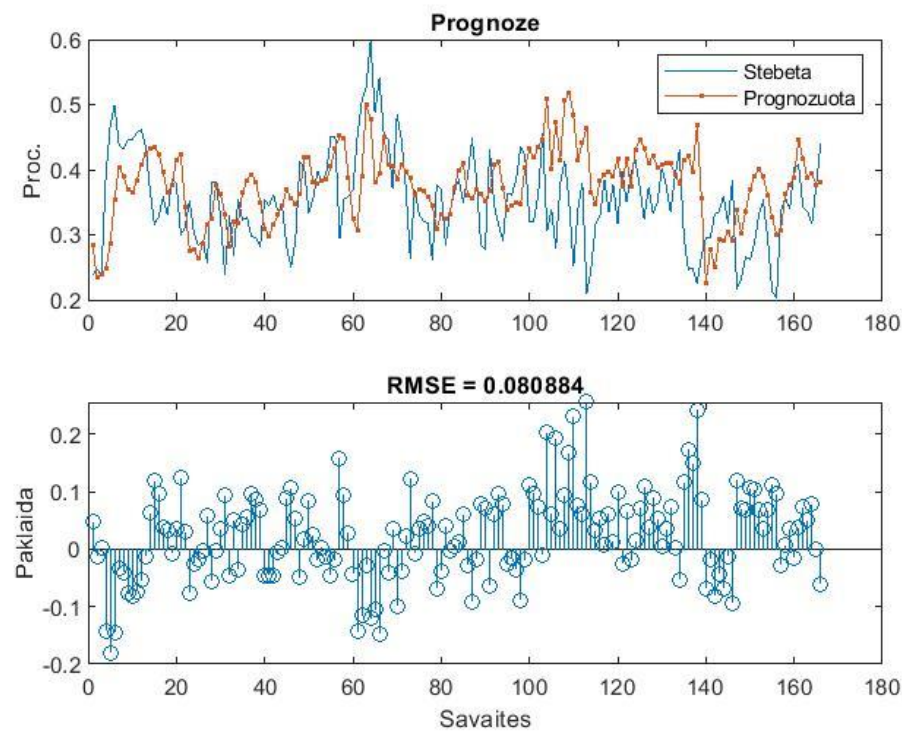

1 paveikslas. Teigiamų sentimentų prognozavimo palyginimas su stebėtomis reikšmėmis (sudaryta autoriu MATLAB programa)

Pirmame grafike yra atvaizduotos modelio stebètų ir prognozuotų reikšmių kreivès. Galime matyti, kad prognozuotų reikšmių kreivès forma labai nedaug skiriasi nuo realių reikšmių kreivès. Tuo ịsitikinti padeda apskaičiuota bendra visos laiko eilutės paklaida, kuri yra lygi 0,080884. Kuo mažesnè paklaida, tuo tikslesnès yra prognozių reikšmès, todèl galima teigti, kad naudojamas LSTM modelis teigiamų sentimentų prognozavimą atliko labai tiksliai. Toks didelis tikslumas yra dar ir dèl to, kad standartizuotų duomenų pasiskirstymo amplitudè nèra didelè, t. y. visos laiko eilutès didžiausia standartizuota reikmė yra $60 \%$, o mažiausia $20 \%$.

2 paveiksle yra pateikti teigiamų sentimentų, išreikštų procentais nuo visų balsavusių individualių investuotojų, istorinių duomenų ir atlikto prognozavimo grafikai.
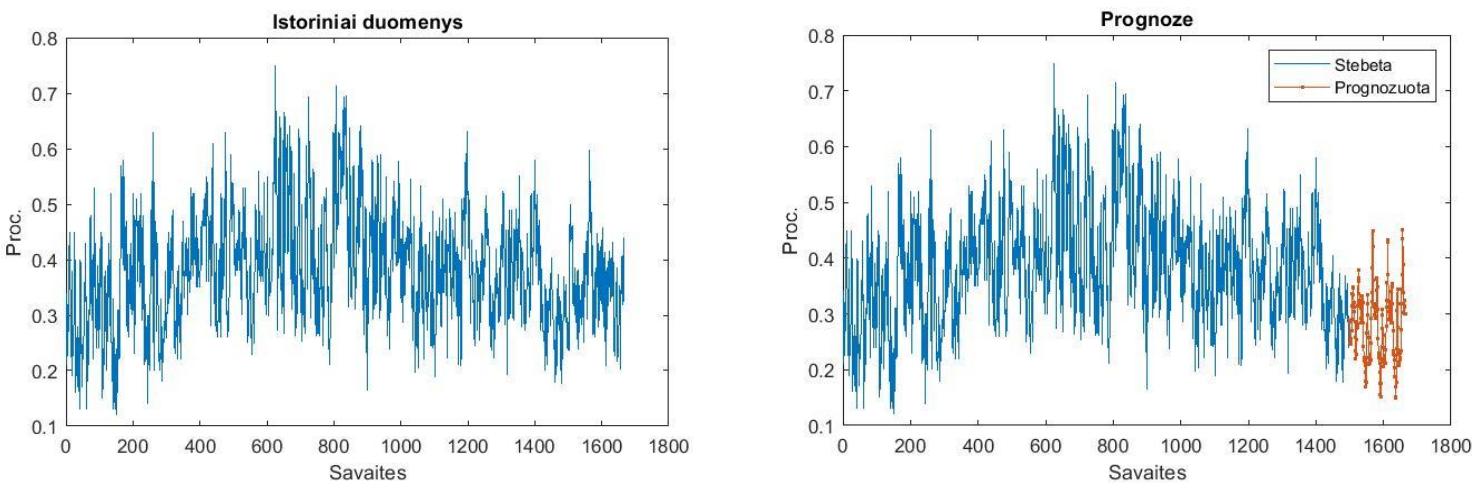

2 paveikslas. Teigiamų sentimentų istoriniai duomenys bei prognozės naudojant LSTM metodą (sudaryta autorių)

Pagal pateiktus grafikus 2 paveiksle galima atlikti istorinių duomenų bei prognozuotų reikšmių palyginimą. Kaip prieš tai buvo minèta, modelis iš visos turimos laiko eilutès atliko paskutinių $10 \%$ duomenų prognozavimą. 
Galima matyti, kad prognozès nuo realių reikšmių nedaug skiriasi. Skirtumas atsiranda dèl modelio prognozavimo paklaidos bei dar ir dèl to, kad modelio mokymuisi naudojami standartizuoti istoriniai duomenys.

Antroji nagrinejjama kategorija yra neutralūs sentimentai. Tai investuotojai, kurie nèra jautrūs nei teigiamiems nei neigiamiems sentimentams ir jie nèra apsisprendę dèl konkrečios finansinès priemonès vertès pokyčio ateityje (García Petit et al., 2019).

3 paveiksle yra pateikti grafikai, kurie vaizduoja modelio mokymąsi bei apskaičiuotas paklaidas. Neutralūs sentimentai išreikšti procentais nuo visų balsavusių individualių investuotojų Pateiktuose grafikuose galima matyti, kaip modelio stebėtų standartizuotų duomenų kreivė skiriasi nuo jo prognozuotų reikšmių kreivės. Skirtumas nėra didelis, bet yra šiek tiek didesnis nei prieš tai nagrinètu atveju, nes šiuo atveju gauta bendra visų duomenų RMSE paklaida yra didesnè, ji lygi 0,087537. Tačiau toks skirtumas nèra reikšmingas, vadinasi tiek pirmu atveju, tiek antru, atliktas prognozavimas yra labai tikslus.
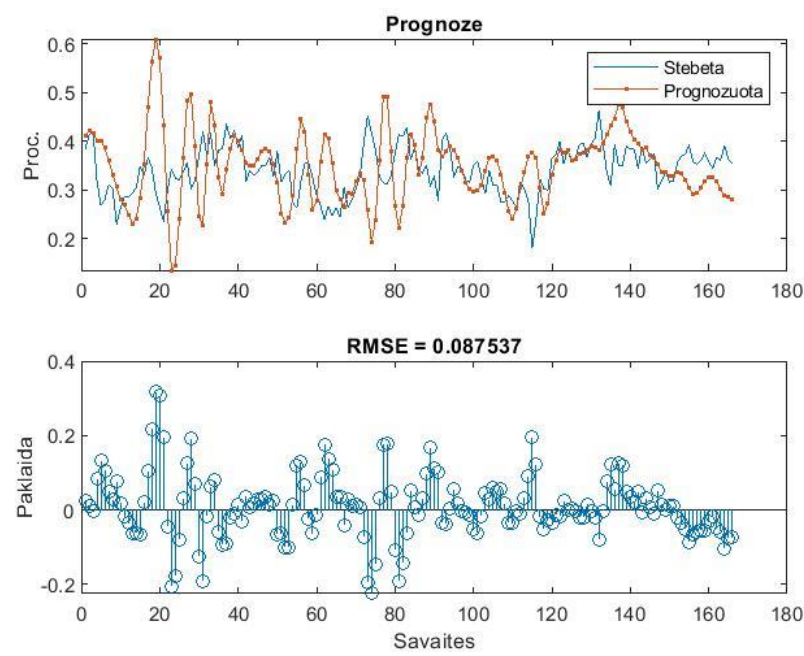

3 paveikslas. Neutralių sentimentų prognozavimo palyginimas su stebètomis reikšmėmis (sudaryta autorių MATLAB programa)

4 paveiksle pateikti neutralių sentimentų, išreikštų procentais nuo visų balsavusių individualių investuotojų, istorinių duomenų ir prognozės grafikai. Iš pateiktų grafikų galima matyti, kad modelio atliktas prognozavimas yra labai tikslus, kurio reikšmès yra ne tik labai panašios ị realiąsias, bet bendra kitimo tendencija yra išlaikyta vienoda. Vadinasi tokị modeli galima naudoti ateities reikšmių prognozavimui nebijant, kad bus iškraipyta bendra duomenų tendencija.
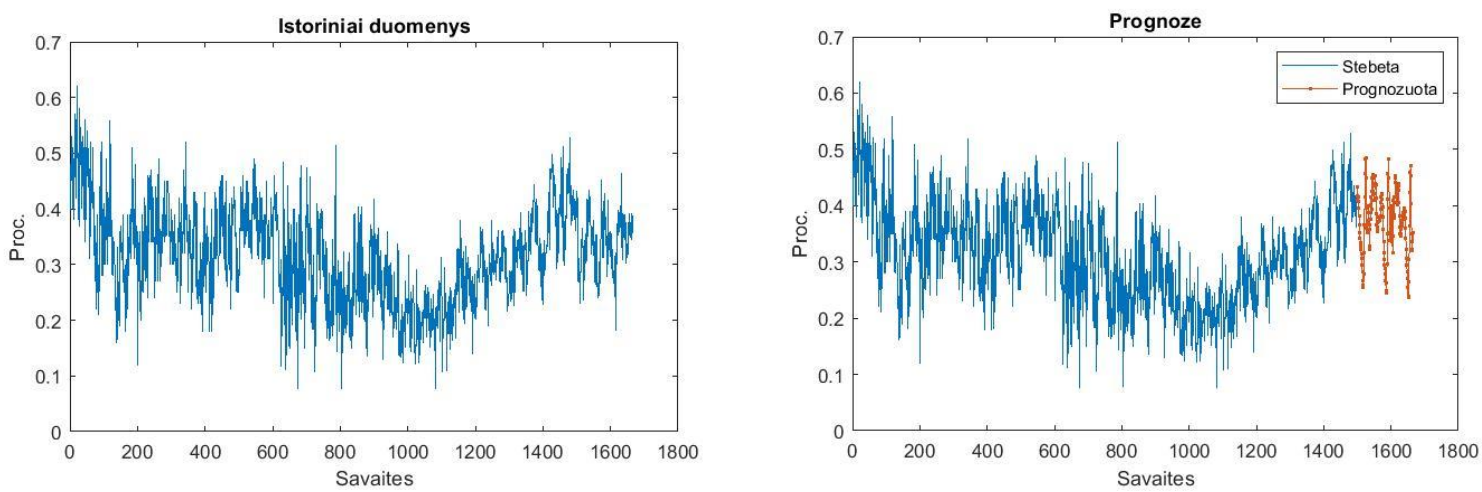

4 paveikslas. Neutralių sentimentų istoriniai duomenys bei prognozės naudojant LSTM metodą (sudaryta autorių)

Trečioji nagrinëjama kategorija yra meškų arba, kitaip tariant, tai yra neigiami investuotojų sentimentai. Tai yra investuotojai, kurie yra suinteresuoti konkrečios finansinès priemonès vertès kritimu ir dèl ateities yra nusiteikę negatyviai (Derakhshan ir Beigy, 2019). 5 paveiksle pateikiami modelio mokymosi bei paklaidų grafikai. Neigiami sentimentai išreikšti procentais nuo visų balsavusių individualių investuotojų. 

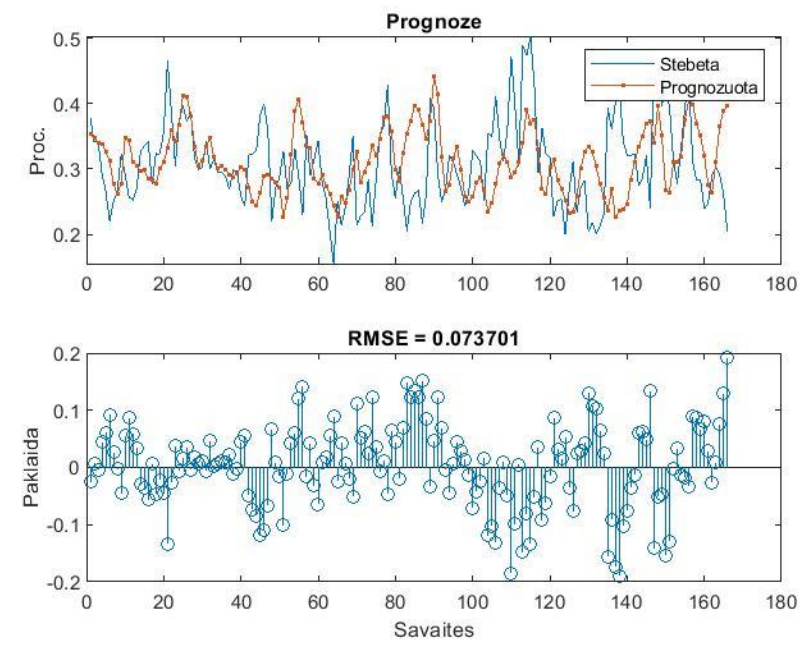

5 paveikslas. Neigiamų sentimentų prognozavimo palyginimas su stebètomis reikšmėmis (sudaryta autorių MATLAB programa)

Iš 5 paveiksle pateiktų grafikų galima matyti, jog stebètų duomenų bei prognozuotų duomenų kreivès yra panašios. Taip pat kaip ir prieš tai nagrinètais atvejais, šiuo atveju paklaida yra labai maža. Lyginant su kitu sentimentų prognozavimo paklaidomis, neigiamu sentimentų prognozavimas yra tiksliausias, nes jo RMSE paklaida yra mažiausia, lygi 0,073701 .

6 paveiksle pateikiami neigiamų sentimentų, išreikštų procentais nuo visų balsavusių individualių investuotojų, istorinių duomenų bei prognozės grafikai.
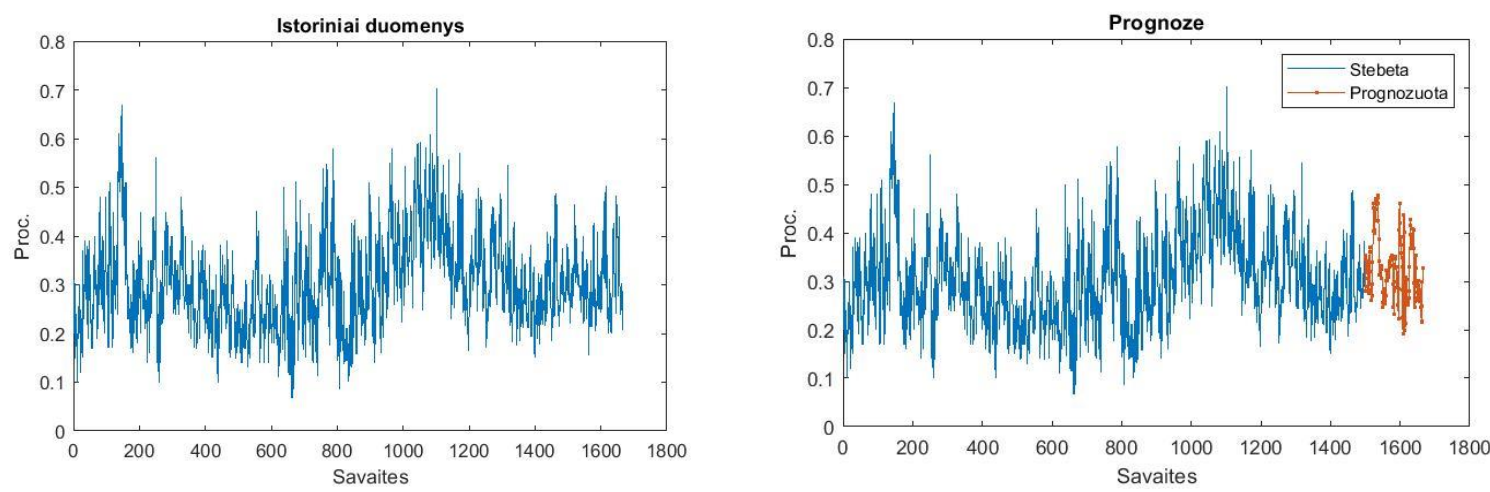

6 paveikslas. Neigiamų sentimentų istoriniai duomenys bei prognozės naudojant LSTM metodą (sudaryta autorių MATLAB)

Pagal 6 paveiksle pateiktus grafikus galima matyti, kad prognozuotos reikšmės yra labai panašios ị realias reikšmes. Grafikų skirtumas yra labai nedidelis, be to abiejuose grafikuose yra išlaikyta tokia pati bendra duomenų kitimo tendencija, vadinasi galima teigti, kad toks modelis yra patikimas ir gali būti naudojamas ateities reikšmiu prognozavimui.

Apibendrinant visų atliktų sentimentų prognozavimo rezultatus, galima teigti, kad prognozavimui pasirinktas LSTM metodas yra patikimas ir tinkamas naudoti. Visais trimis atvejais paklaidos buvo gautos labai mažos, vadinasi atliktas modelio gebëjimo prognozuoti testas yra rezultatyvus. Tačiau reikia atkreipti dèmesị ị tai, kad standartizuotų duomenų visais trimis atvejais amplitudès buvo mažos, vadinasi tai yra vienas iš pagrindinių veiksnių, kodèl prognozavimo paklaidos buvo gautos tokios mažos, nes jeigu duomenų amplitudès būtų žymiai didesnès, tai ir paklaidos būtų didesnès.

Kiekvienas investuotojas yra suinteresuotas konkrečių finansinių priemonių vertès palankiu kitimu, o LSTM metodas puikiai tinka reikšmių prognozavimui investavimo sferoje. Atliktas norimų reikšmių, šiuo atveju investuotojų sentimentų, prognozavimas gali padeti investuotojams priimti racionalius investavimo sprendimus.

\section{Išvados}

Kiekvienas investuotojas prieš atlikdamas investicinius sprendimus nagrinèja turimą informaciją apie dabartinę ir ateities finansinès rinkos situaciją. Tokią informaciją kaupti investuotojai gali pasitelkdami ne tik įvairius finansinių 
priemonių vertès kitimo metodus bei technikas, bet ir nagrinèjant rinkos sentimentus bei atliekant jų prognozavimą. Investuotojų sentimentai nurodo kokios nuotaikos vyrauja rinkoje, ar labiau pesimistinès, ar optimistinės. O pagal tai investuotojai gali nuspèti ar finansinių priemonių verte kris ar kils. Sentimentų prognozavimui atlikti vienas naujausių būdų yra naudojant dirbtinio intelekto algoritmus. Tačiau atlikus mokslinès literatūros analizę buvo pastebėta, kad dirbtinis intelektas dar nèra labai plačiai naudojamas rinkos sentimentų prognozavimui.

Tyrimo metu buvo susipažinta su dirbtinio intelekto naudojimu ir išsiaiškinta, kad laiko eilutės prognozavimui labiausiai tinkamas yra giliojo mokymosi LSTM metodas. Šio metodo algoritmas buvo naudojamas atskirai prognozuojant tris skirtingas investuotojų sentimentų rūšis: teigiamus, neigiamus bei neutralius sentimentus. Kiekvienu atveju buvo gautos labai mažos RMSE paklaidos: 0,07-0087, o tai reiškia, kad modelio atliktos prognozès yra labai tikslios. Be to, palyginus istorinių duomenų bei atliktų prognozių grafikus, galima pastebèti ir įsitikinti, kad kreivès skiriasi labai nedaug. Vadinasi toks algoritmas yra patikimas ir tinkamas sentimentų ateities reikšmių prognozavimui.

Šiame darbe rinkos sentimentai nebuvo susieti su jokiais finansų rinkos instrumentais ar jų kainomis, nenagrinėta kas daro įtaką pokyčiams: sentimentai keičia finansų rinkos rodiklius ar rinkos pokyčiai lemia sentimentų pokyčius. Prognozuojami sentimentai gali būti susieti su kitais finansų rinkos rodikliais, o nagrinėtas metodas gali būti integruotas ị investuotojo prekybos strategiją ar paramos sistemą.

\section{Literatūra}

AAII Investor Sentiment Survey. (2019). https://www.aaii.com/sentimentsurvey/

Barber, B. M., \& Odean, T. (2013). The behavior of individual investors. Handbook of the Economics of Finance, 2(Part B), 1533-1570. https://doi.org/10.1016/B978-0-44-459406-8.00022-6

Beer, F., \& Zouaoui, M. (2012). Measuring investor sentiment in the stock market. SSRN Electronic Journal, 1-30. https://doi.org/10.2139/ssrn.1939527

Ben-Rephael, A., Kandel, S., \& Wohl, A. (2012, July). Measuring investor sentiment with mutual fund flows. Journal of Financial Economics, 104, 363-382. https://doi.org/10.1016/j.jfineco.2010.08.018

Bikas, E. ir Kavaliauskas, A. (2010). Lietuvos investuotojų elgsena finansų krizès metu. Business: Theory and Practice, 11(4), 370-380. https://doi.org/10.3846/btp.2010.40

Boulemtafes, A., Derhab, A., \& Challal, Y. (2020). A review of privacy-preserving techniques for deep learning. Neurocomputing, 384, 21-45. https://doi.org/10.1016/j.neucom.2019.11.041

Bouteska, A. (2019). The effect of investor sentiment on market reactions to financial earnings restatements: Lessons from the United States. Journal of Behavioral and Experimental Finance, 24, 100241. https://doi.org/10.1016/j.jbef.2019.100241

Chen, C., Zhang, P., Liu, Y., \& Liu, J. (2019). Financial quantitative investment using convolutional neural network and deep learning technology. Neurocomputing (in press). https://doi.org/10.1016/j.neucom.2019.09.092

Derakhshan, A., \& Beigy, H. (2019). Sentiment analysis on stock social media for stock price movement prediction. Engineering Applications of Artificial Intelligence, 85, 569-578. https://doi.org/10.1016/j.engappai.2019.07.002

Fischer, T., \& Krauss, C. (2018). Deep learning with long short-term memory networks for financial market predictions. European Journal of Operational Research, 270(2), 654-669. https://doi.org/10.1016/j.ejor.2017.11.054

García Petit, J. J., Vaquero Lafuente, E., \& Rúa Vieites, A. (2019). How information technologies shape investor sentiment: A web-based investor sentiment index. Borsa Istanbul Review, 19(2), 95-105. https://doi.org/10.1016/j.bir.2019.01.001

He, Z., He, L., \& Wen, F. (2019). Risk compensation and market returns: the role of investor sentiment in the stock market. Emerging Markets Finance and Trade, 55(3), 704-718. https://doi.org/10.1080/1540496X.2018.1460724

Kumari, J. (2019). Investor sentiment and stock market liquidity: Evidence from an emerging economy. Journal of Behavioral and Experimental Finance, 23, 166-180. https://doi.org/10.1016/j.jbef.2019.07.002

Lapanan, N. (2018). The investment behavior of socially responsible individual investors. Quarterly Review of Economics and Finance, 70, 214-226. https://doi.org/10.1016/j.qref.2018.05.014

Maknickiene, N., Lapinskaite, I., \& Maknickas, A. (2018). Application of ensemble of recurrent neural networks for forecasting of stock market sentiments. Equilibrium, 13(1), 7-27. https://doi.org/10.24136/eq.2018.001

Maknickienè, N., \& Vaškevičiūtè, A. (2017). Comparison of sentiments data extraction and prediction. Innovative Infotechnologies for Science, Business and Education, 1(22), 14-20.

Matlab deep learning algorythm. (2019). https://ch.mathworks.com/help/deeplearning/examples/time-series-forecastingusing-deep-learning.html

Pandey, P., \& Sehgal, S. (2019). Investor sentiment and its role in asset pricing: An empirical study for India. IIMB Management Review, 31(2), 127-144. https://doi.org/10.1016/j.iimb.2019.03.009

Paschen, U., Pitt, C., \& Kietzmann, J. (2020). Artificial intelligence: Building blocks and an innovation typology. Business Horizons, 63(2), 147-155. https://doi.org/10.1016/j.bushor.2019.10.004

Picasso, A., Merello, S., Ma, Y., Oneto, L., \& Cambria, E. (2019). Technical analysis and sentiment embeddings for market trend prediction. Expert Systems with Applications, 135, 60-70. https://doi.org/10.1016/j.eswa.2019.06.014

Ruan, Q., Wang, Z., Zhou, Y., \& Lv, D. (2020). A new investor sentiment indicator (ISI) based on artificial intelligence: A powerful return predictor in China. Economic Modelling, 88, 47-58. https://doi.org/10.1016/j.econmod.2019.09.009 
Ryu, D., Kim, H., \& Yang, H. (2017). Investor sentiment, trading behavior and stock returns. Applied Economics Letters, 24(12), 826-830. https://doi.org/10.1080/13504851.2016.1231890

Šiurkute, D. ir Jakaitienè, A. (2009). Infliacijos prognozavimas faktoriniais modeliais. Lietuvos matematikos rinkinys, 230234.

Vo, N. N. Y., He, X., Liu, S., \& Xu, G. (2019). Deep learning for decision making and the optimization of socially responsible investments and portfolio. Decision Support Systems, 124, 113097. https://doi.org/10.1016/j.dss.2019.113097

Yang, C., \& Wu, H. (2019). Chasing investor sentiment in stock market. North American Journal of Economics and Finance, 50, 100975. https://doi.org/10.1016/j.najef.2019.04.018

Zhou, G. (2017). Measuring investor sentiment. SSRN Electronic Journal, 1-21. https://doi.org/10.2139/ssrn.3051414

\section{FORECASTING OF MARKET SENTIMENTS USING ARTIFICIAL INTELLIGENCE}

\section{Nijolè MAKNICKIENĖ, Jovita MASĖNAITÉ}

Abstract. Every investor faces the challenge of making efficient investment decisions. There are many methods to analyze the causes of changes in the financial market and to predict future trends based on such information. One way is to predict investors sentiment. This type of study is not extensively studied in the scientific literature, so the purpose of this article research is to perform prediction of different investor sentiment and to evaluate the reliability of the model used for prediction, i.e. reaching to discover a reliable sentiment prediction algorithm. Artificial intelligence deep learning short-term memory (LSTM) network method and graphical representation of the obtained results are used for the research. The study found that the margin of error (RMSE) obtained for each sentiment prediction case was very low, which means that the algorithm used for prediction is very reliable. Investors using this algorithm can help themselves better study market trends, but other financial market research methods should be used in parallel to make investment decisions as efficiently as possible.

Keywords: investors behavior, market sentiment, artificial intelligence, deep learning, long-term memory networks, forecasting. 